\title{
Practical Problems of Implementing Selected Procedures Determining Course of Borders ${ }^{* *}$
}

\begin{abstract}
A large part of the surveying work reported to geodetic and cartography documentation centers are those that, in the end, result in the determination of a border in a field. Until the amendment of the regulation on the Land and Buildings Register, the determination of the borders of individual land parcels was possible only due to acting on the basis of the Geodetic and Cartographic Law. Currently, it is possible to use the procedure for determining the course of the borders of plots performed on behalf of private entities for the purpose of updating the Land and Buildings Register. Determination of the course of the boundaries in a field is also possible on the basis of the performed tasks of determining the border points previously disclosed in the land register or the resumption of border marks.

This article analyzes geodetic studies based on Art. 39 of the Geodetic and Cartographic Law, and in accordance with §39 of the Regulation on the Land and Buildings Register made for the purpose of updating the Land and Buildings Register. On the basis of the analysis, geodetic and legal problems were identified, which are caused by the imprecise regulations encountered by the contractors while carrying out activities aimed at defining the borderline of the field. The author also analyzes the materials that, in light of the binding legal provisions, may serve as a basis for carrying out the renewal of border marks, setting border points, and determining the course of borders.
\end{abstract}

Key words: setting boundaries, resuming borders, land register

* AGH University of Science and Technology, Faculty of Mining Surveying and Environmental Engineering, Department of Engineering Surveying and Civil Engineering, Krakow, Poland

** The paper was prepared within the scope of the Dean Project of the faculty of Mining Surveying and Environmental Engineering (AGH University of Science and Technology) 


\section{Introduction}

Approximately 30\% of the geodetic work [4] reported to the District Geodetic and Cartographic Documentation Centers (PODGiK) are those that result in defining borders in a field. According to the binding legal regulations, the borders can be determined in accordance with the Geodetic and Cartographic Law [18] in the demarcation proceedings or for land register purposes in the mode of the Regulation on the Land and Buildings Register [14]. The course of the boundaries on the ground can also be determined on the basis of the performed tasks of setting border points or the resumption of border marks performed in the mode of Art. 39 of the Geodetic and Cartographic Law.

As highlighted in [7], until the amendment of the Regulation on the Land and Buildings Register [14], determination of the boundary course of individual record parcels was only possible in the mode of the Geodetic and Cartographic Law Act [18]. The amendment introduced by the legislator [16] made it possible to use the determining course of boundary procedure during the updating of the Land and Buildings Register for private individuals [7].

Real estate demarcation is not a geodetic activity willingly performed due to the long time to settle [1,3] and its complexity of work [10]. The procedure for the designation of border points or the resumption of border marks for technical reasons does not always apply because, at the National Geodetic and Cartographic Resource (PZGiK), there are not always materials that present their original locations [8, 9]. The use of the boundary-setting procedure for updating the land register is beneficial because it facilitates and accelerates the geodetic work, but it also raises reasonable doubts.

This article analyzes geodetic studies based on Art. 39 of the Geodetic and Cartographic Law [18] and pursuant to $\S 39$ of the Regulation on the Land and Buildings Register [14] made for the purpose of updating the Land and Buildings Register. Based on the analysis, the geodetic and legal problems caused by the imprecise regulations encountered by the surveyors during the course of activities aimed at defining borders in the field were identified. The carried-out work also analyzes the materials that, in light of the binding legal provisions, may serve as a basis for carrying out the renewal of border marks, setting border points, and determining the course of borders.

\section{Terminology for Determining Carried-out Activities}

By analyzing the technical services performed by the contractors, it can be seen that the qualified surveyors confuse the concept of border marks with boundary points. As a consequence, this leads to the wrong determination of what they do on the ground. According to the regulation on the demarcation of the property, a boundary point determines the course of the boundaries of the property, while 
a border mark is the "sign of permanent material placed at the boundary point or permanently landed at this point" [13]. The regulation also defines the stabilization and temporary fixation of boundary points. Stabilization involves the permanent fixation of the cut-off point by placing a limit mark on it. The most-common border marks found on the ground are boundary stones, border guards, and concrete boundaries. Temporary fixation of the cut-off point is to mark its position in the field (using, for example, wooden stakes or metal pins) without permanent stabilization.

Prior to performing the point determination and resumption of the border marks, the material obtained from the PZGiK (National Geodetic and Cartographic Resource - NGaCR) should be analyzed, as it can be determined whether the border had been previously stabilized. This will allow one to correctly identify the actions one takes because, according to Art. 39 of the Geodesy and Cartography Act, renewals may only be subject to border marks that were previously subject to stabilization. If there is no permanent stabilization in the form of a border mark, then the determination of the boundary points should be carried out, provided that the relevant data is contained in the PZGiK (NGaCR).

When performing border-determining activities for the purpose of updating the Land and Buildings Register, the surveyor is not obligated to permanently stabilize the boundaries. This can only take place on the initiative and at the expense of the interested parties and may only concern points established on the basis of consistent statements by the parties ( $§ 39$ (4) of the Regulation on the Land and Buildings Register). In light of the regulations mentioned above, it is not possible to stabilize the border marks in the case of a disputed border.

\section{Choosing Mode of Procedure}

The procedure for the resumption of border marks and the designation of boundary points was laid out in Art. 39 of the Geodetic and Cartographic Law [18]. According to the act, the resumption of the border marks is carried out for the signs that were previously determined but have been moved, damaged, or destroyed (if there are materials in the PZGiK [NGaCR] that allow us to determine their original positions). The task of setting boundary points is made for points previously disclosed in the records of the Land and Buildings Register for which no permanent stabilization in the form of a border mark has been made if there are documents capable of determining their locations. These are technical activities performed by surveyors having the powers in Scope 2 performed on the order of the parties after the prior notification of work in the relevant local PODGiK (District Geodetic and Cartographic Documentation Centre - DGaCDC). On the basis of the performed activities, the surveyor draws up a technical service and sends it to the PODGiK (DGaCDC) for admission to the resource. These activities should not cause changes to the Land and Buildings Register database (LaBR) nor any changes to the course of the borders. According to 
the judgment of the Supreme Administrative Court, these are material and technical activities restoring only a certain condition on the ground [19].

The procedure for determining the course of the boundaries is applicable if there is no documentation prepared in the PZGiK (NGaCR) from: delimitation of real estate, consolidation and land exchange proceedings, division of real estate, merger and division proceedings, court or administrative proceedings, establishing land register, or the data contained in the aforementioned documentation is unreliable. As highlighted in [7], the determination of the boundaries of the record parcel made as part of updating the Land and Buildings Register made in the mode of $\S 39$ of the Regulation on the Land and Building Register [14] need not to be approved by an administrative decision. Existing laws do not impose such an obligation on district governors. When the organ responsible for the land register does not issue a decision approving the course of a border, it is a technical procedure, and the boundaries set during such activities are not legally binding and cannot be regarded as legal boundaries. The record of these activities after positive verification will be part of the resource, and any surveyor performing future work on these boundaries will be able to use these documents (but will not need to indicate a border in the same location). The legislator did not specify how many times the course of a single boundary can be determined [7]. The lack of specific regulations on the aforementioned issues may lead to future arguments - the different course of boundaries indicated by two surveyors may be the cause of a conflict.

In practice, cases may be encountered where, at the request of an authorized party, an administrative decision is issued by the organ responsible land register, which approves the course of the border according to the survey performed by the surveyor for the purpose of updating the Land and Buildings Register. This solution seems reasonable because, in accordance with the view of Hycner and others [6, 8], the boundaries approved by the final administrative decision can be regarded as legal boundaries. Doubts are raised by the decision approving the course of the disputed boundary. According to $\S 39$, Sec. 3 of the regulation on the Land and Building Register [14], the boundaries shall be determined by the contractor in the event of a dispute after a prior analysis of the materials. In light of the applicable laws, any border (even the subject of a dispute) is established. The doubts in this case raise the question of whether the district governor is a competent body to issue a decision approving the disputed border. In its verdict of July 29, 2011, the Supreme Administrative Court stated that "the boundary of the property determines the extent of its ownership, so the dispute over this border is in essence a dispute over the scope of the right of property, which is not a matter for the registration proceedings, but for demarcation" [20]. This view was shared by the Voivodeship Administrative Court in Kielce, which stated that "any disputes that occurred as a result of the recorded changes concerning, inter alia, the course of borders cannot be resolved in the proceedings of the land register" [21]. In another judgment, it was noted that "(...) as the course of the boundaries between the plots is disputable (...), the conduct of proceedings concerning the change in the land register 
became devoid of purpose. In this case, determining the course of the boundaries of real estate may occur in the demarcation proceedings" [22]. The case-law cited shows that, in the case of a dispute arising during the determination of boundaries, the district governor should not issue a decision approving the disputed border, as the arguments in the border sections may only be resolved in the demarcation proceedings.

Prior to setting up the boundary line in a field, the surveyor is obligated to analyze the materials received from PODGiK (DGaCDC) [14]. On the basis of the analysis, it is stated whether the boundaries of the parcel had been previously determined. Then, the surveyor investigates the possibility of applying the border-mark-resumption procedure and the designation of boundary points. If it is found that there is no documentation under which the resumption and boundaries may be performed, or if the data in this documentation is unreliable pursuant to $\S 37.1$ of the regulation on the Land and Buildings Register [14], border determination procedures should be carried out in accordance with $\S 39$ of the abovementioned regulation.

\section{Materials on which Determination of Borders is Based}

In the National Geodetic and Cartographic Resource, one can find materials defining the course of the boundaries of record parcels with differing accuracy [2]. The data disclosed in the resource rarely allows for the direct determination of boundary points from the coordinates (especially in rural areas). There are no specific regulations in the legislation that determine which documents can be used to set boundary points or resume border marks and when to use boundary-determination procedures. In practice, this can cause problems with how to select a procedure for determining the border in a field. In the literature [5, 7], the main view is that only those legal boundaries that were approved by a final administrative decision or a final court decision can be resumed. It is important that these boundaries cannot be the subject of a dispute (the decision of the District Court in Słupsk of August 8, 2013, file No. IV Cz 417/13 [11]). As a consequence, the resumption of the border marks in the case of a previous division or merger could only be subject to newly designed borders, whereas the external borders that were assumed to be split or merged should no longer be subject to such a renewal. When analyzing the technical documentation, one will find that the view presented above is not reflected in practice. Surveyors include all points of collapse of the boundaries of a parcel subject to a prior division or consolidation if they have sufficient materials to clearly identify their original location when they carry out the resumption of border marks.

By analyzing the technical documentation that resulted from the division of the property, it can be seen that the geodetic work done before 1980 did not always end with the definition of the coordinates of the collapse points in the coordinate system at that time; the source materials resulting from these operations do not always allow for the determination of their original positions. In such cases, the renewal of the border 
marks is not practiced, but the execution of the procedure is made pursuant to $\S 39$ of the regulation on the Land and Buildings Register [14]. At that time, the newly designed boundaries will be subject to determination despite being approved by the final administrative decision, because they cannot be resumed due to a lack of suitable materials.

It should be emphasized that there are cases where the documentation centers try to force surveyors to follow certain procedures that contractors should apply in the given cases. It should be noted that, according to $\S 6.1$ of the Regulation on Technical Standards [14], it is the surveyor who analyzes the material received from a resource and determines which procedure should be used. A PODGiK (DGaCDC) employee verifying an operation cannot direct the surveyor on how to proceed; yet, such situations occur in practice.

Due to the fact that the binding provisions of the law do not clearly regulate the procedure of defining the course of the borders, the documents that are most-often used for such work are analyzed. The analysis was carried out to identify materials that, in light of the applicable rules, could provide the basis for resuming border marks, setting boundary points, and determining the boundaries.

\subsection{Materials from Pre-War Consolidations}

In the areas of the former Russian partition area, materials made during the pre-war mergers can be found in PZGiK (NGaCR) (Figs. 1 and 2). In most of the analyzed work, the surveyors carried out activities of setting border points or resuming border marks on their basis (depending on whether the point of collapse of the borders was stabilized). It can be noted that these are interesting works, especially from a technical point of view; they require the performer to carefully analyze the materials that were created over a long period of time.

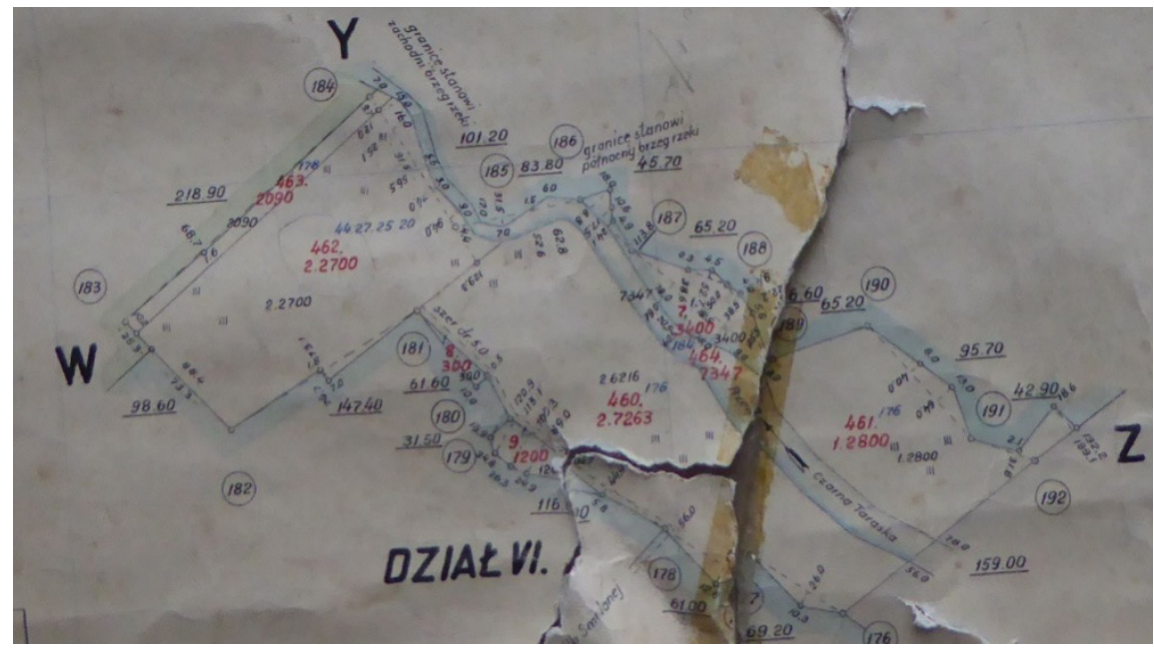

Fig. 1. Excerpt of initial example of integration map created in 1940s 


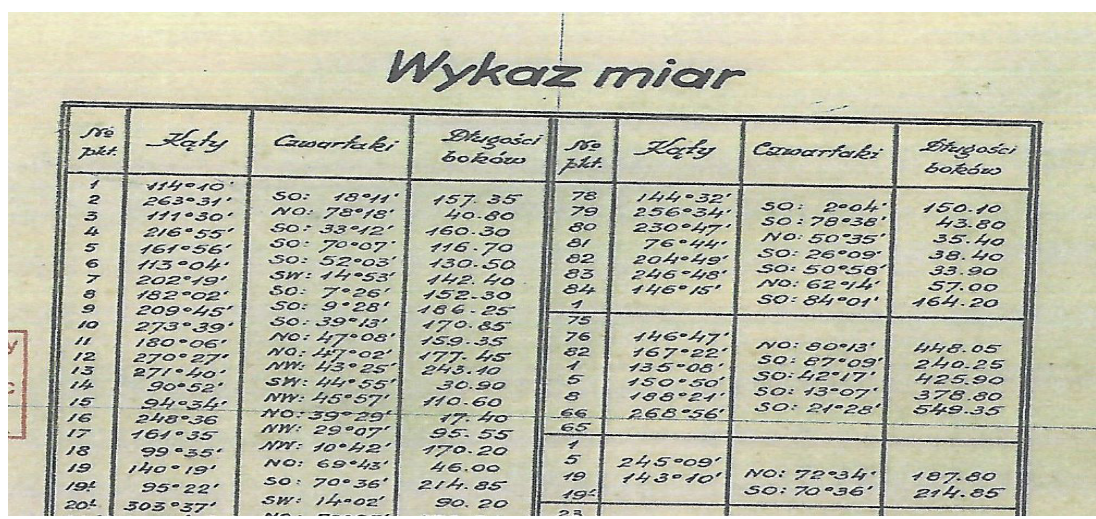

Fig. 2. Excerpt of list of measures forming part of $40^{\text {th }}$ meridian map

In the pre-war years, only classical measurement methods were used in the preparation of such materials, and the position of the geodetic measurement matrix points was determined in the local coordinate systems adapted to the work. So far in the area, one can find the border marks and the measurement matrix points from this period; therefore, on the basis of the above-shown materials, surveyors are able to correctly determine the course of the boundaries in many cases if they manage to find a sufficient number of measurement matrix points to transform the coordinates from the local to the valid layout. This possibility is permitted in $\S 30$, Sec. 2 of the Regulation on Technical Standards [15].

In the case of resuming border operations based on the above material, doubts may arise as to whether such a practice allows for the resumption of marks to the extent specified in the applicable law; i.e., to the accuracy of the details of the accuracy of Group I ( $\$ 29.1$ of the Regulation on Technical Standards) or with the precision of $0.30 \mathrm{~m}$ with respect to measurement matrix Grade I points (§ 61 (1) of the Regulation on the Land and Buildings Register). According to the judgment of the Voivodeship Administrative Court in Krakow [23], in cases where the data disclosed in the PZGiK (NGaCR) does not meet the standards in force, it is necessary to carry out border demarcation in the manner of the regulation on the Land and Buildings Register [14].

In practice, the accuracy of determining the original location of the border mark on the basis of the after-merging materials does not always meet the criteria laid down in the current legislation, but the contractor still decides to carry out border renewal (which, in light of the case-law cited, appears to be incorrect).

\subsection{Complementary Measurement Materials}

In PZGiK (NGaCR), one can find materials created in the 60 s and 70 s that were made for the purpose of establishing land registers in Poland. These documents may include measurement outlines (Fig. 3) or a cadastral map. When analyzing the technical reports, it was noted that the surveyors performed most of the work in setting 
the boundaries for the purpose of updating the Land and Buildings Register on the basis of the materials mentioned above. The reason for choosing the boundary-determining procedure based on the metrics outlined in the measurement outline is that this document does not always allow one to determine the course of the boundaries to the extent required by applicable law. Nowadays, it is difficult to clearly identify the situational details in a field on the basis of which the surveyors measured and made a measurement outline more than 50 years ago. Over time, land development has changed, and it is not always possible to reconstruct the course of the measuring line, especially in those cases where there was no permanent stabilization of the points on which the measuring lines were assumed.

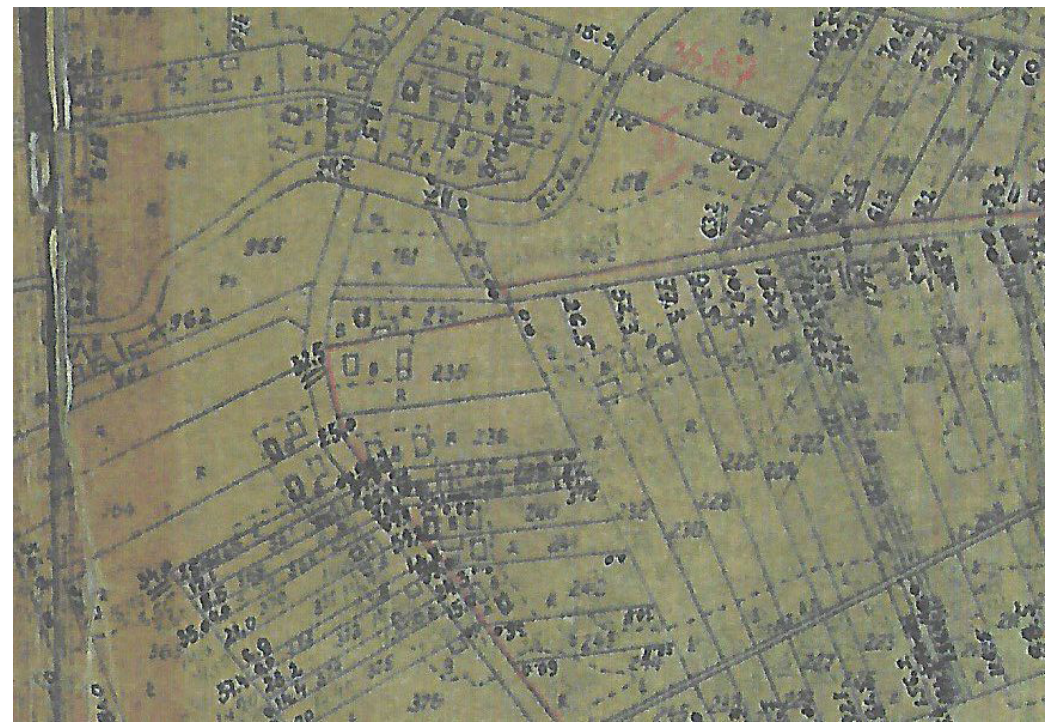

Fig. 3. Excerpt of 1967 measurement outline

One can meet the viewpoint where surveyors determine the accuracy of the measurements presented in the measurement outline to approximately $0.5 \mathrm{~m}$ based on their many years of work experience. Such a low accuracy of the determined boundaries confirms the view that, in this case, the measurement outline is not a document based on which the original course of the boundaries can be reproduced to the accuracy required for the situational details of the accuracy Group I. This view was also shared by the District Court in Łomża, stating that (Order of the SR in Łomża of October 09, 2014, Signature of the Register I Ca 202/14 [12]):

supplementary measurements made during the years 1958-1963 when establishing a land register did not meet the criteria resulting from the current regulations. [...] these marks cannot determine the course of the boundary between real estate plots Their location was determined on the basis of the geodetic documentation, which, as imprecise and non-compliant, could not be the basis for such measurements. 
It is not usually possible to use the border-mark-restoration process on the basis of the measurement outline, as sustained border stabilization has rarely been achieved at the time of drawing up such materials, and the accuracy of the boundary points on the basis of the outline of most of the work analyzed did not meet the criteria required by law; therefore, it is also impossible to carry out the task of setting the boundary points. Therefore, the choice of the border-setting procedure based on the measurement outline seems correct.

It may happen that the measurement outlines as complementary measurements of the previous mergers only thicken the measurement lines shown on the merger headings. In such cases, one can determine the course of the boundaries indirectly through the meridian and directly on the basis of the outline. If these materials allow the accuracy of the I group to indicate the location of the limit points, then it would appear that it is possible to perform the task of setting the limit points in this case.

\subsection{Other Materials}

Surveyors perform the activity of setting boundary points (the resumption of border marks in the examined areas was not performed because no fixed stabilization was performed at the boundary points) based on the updating of the land registry in the 1990s. These studies ended in the determination of the coordinates of the points of collapse of the boundaries in the local coordinate systems, so it can be concluded that there are documents in the PZGiK (NGaCR) on the basis of which the original course of the borders can be reproduced.

It should be kept in mind, however, that the accuracy of the location of the boundary point may be low due to the different measurement methods [5]. Therefore, when determining the course of the boundaries, it is necessary to check that the materials obtained from the PODGiK (DGaCDC) that allow us to determine the coordinates of the cut point to the required accuracy in the current legislation. If the data does not meet these standards, border demarcation should not be carried out and determined in accordance with $\S 39$ of the Regulation on the Land and Building Register (decision of the District Court in Łomża, October 09, 2014, Sign I Ca 202/14 [12]). It should be noted that, during the updating for the purpose of modernizing the land register, the real situation on the ground was measured. Very often when measuring borders, it is not checked whether the condition of use in the field corresponds to the demonstrated condition in other documents, such as whether the surface shown in the Land Ownership Act corresponds to the area of the plot calculated under the update. It should be noted that, based on the measurements conducted in the 1960s and 1970s, land and buildings were recorded based on which the Earth Property Acts were issued, on the basis of which property rights have been determined until now; therefore, it should not be suggested merely as the coordinates of the collapse of the boundaries indicated in the land register. 


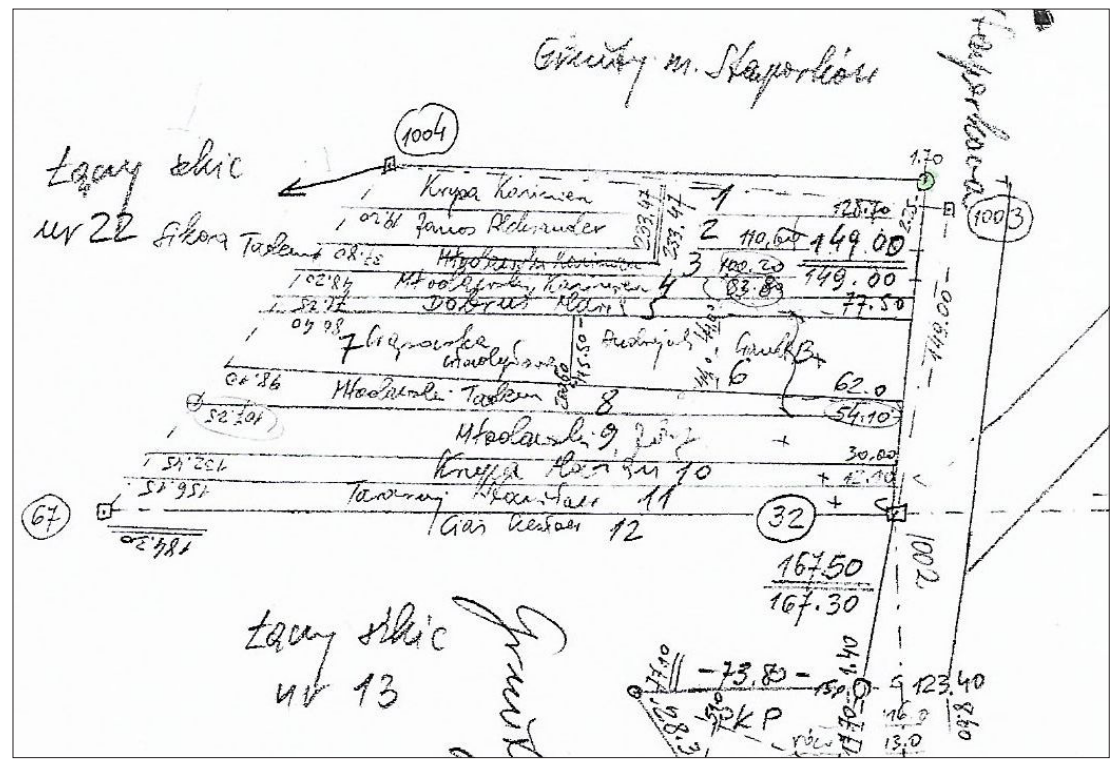

Fig. 4. Excerpt of field sketch made during land registry update in 1980

Other materials defining the course of the boundaries may include a cadastral map. In some areas of Poland, there are cases of performing the task of setting border points on the basis of a cadastral map. These are sporadic cases, because the view is that the boundaries should not be determined on the basis of the cadastral map. The accuracy of defining boundaries on the basis of a cadastral map does not allow us to clearly define the boundary points to the accuracy specified in the applicable law [2]. These borders also cannot be considered legal because a final administrative decision was not approved. It is appropriate to carry out activities on the basis of the cadastral map of the boundary determination in light of Paragraph 39 of the Regulation on the Land and Buildings Register [14].

\section{Problems of Data Reliability Disclosed in PZGiK (NGaCR)}

According to $\S 37$, Par. 1 of the Regulation on the Land and Buildings Register (Regulation, 2001), in the absence of documentation resulting from the PZGiK (NGaCR) resulting from delimitation, division, consolidation and exchange of land, merger and division, and other activities approved by a final administrative decision or a final court decision (or when these are unreliable or do not meet the technical standards [23]), data on the course of the borders should be obtained as a result of field measurements preceded by a determination of the course of the borders.

It is problematic in this case for the legislator to use the concept of reliability of data, because the concept has not been clarified in the legislation in force. In the 
literature, it can be argued that the reliability of the data depends on the accuracy of the location of the boundary point [7]. In practice, a surveyor performing a work after a material analysis declares whether the data disclosed in the PZGiK (NGaCR) is reliable and demonstrates its suitability for further operations. If the contractor finds that the data is unreliable and proves this fact, it seems appropriate in light of the binding legal provisions to apply the procedure of establishing the borders as confirmed by the Voivodship Administrative Court in Krakow [23]:

[...] a necessary condition opening the possibility of obtaining data concerning the course of boundaries of record parcels by way of geodetic surveying preceded by determining the course of borders in the field is to declare the lack of documentation mentioned in $\S 36$ of the regulation or to declare that the data contained therein is not reliable or does not meet the applicable technical standards.

Implementation of $\S 37$, Sec. 1 of the Regulation on the Land and Buildings Register [14] can raise doubts. According to the above, in order to determine the course of the border in the field of the parcel resulting from a merger approved by the final administrative decision, the surveyor should apply the procedure for the resumption of border marks in the manner of Art. 39 of the Geodetic and Cartographic Law [18]. The problem arises when the contractor, declares that the course of one of the boundaries has been erroneously defined after a material analysis, because there is an error in the documentation that caused the incorrect determination of the course of one of the boundaries. Doubts in such cases raise the question of whether the border-fixing procedure can be used and simultaneously to modify the boundary disclosed in the land register database while changing the course of the legal boundary approved by the final administrative decision. $\S 37$, Par. 1 of the Regulation on the Land and Buildings Register [14] allows the surveyor to do so. However, in light of the provisions of the Code of Administrative Procedure [17], it is doubtful whether a decision may be issued at the request of a party approving a predetermined boundary. Although the rules allow for concrete solutions in this case, their implementation may raise doubts.

\section{Conclusions}

An analysis of the surveyed work has shown that the rules governing the procedures for defining boundaries are not clear on many issues. This results in the development of technical documentation that is not always in accordance with the applicable law. The boundary of the record parcel directly determines the extent of the property right, so the rules governing the way the borders are defined should be clear and unmistakable.

There are no specific technical guidelines specifying the documents on the basis of which a surveyor can carry out: a border demarcation, resumption of border marking, or border-fixing - results in the full procedural freedom of contractors. This often 
results in incompatible documentation with the law in force. By determining the border, a surveyor cannot transfer ownership, so it is important to properly analyze the materials received from PZGiK (NGaCR). This allows one to conclude with what accuracy the analyzed documents allow us to determine the course of the boundaries and, consequently, to correctly select the border-determination procedure.

On the basis of the analysis, it was unambiguously stated that the issuing technical guidelines in this area would not only clarify ambiguous provisions and unify the documentation but would facilitate the work of contractors in particular.

\section{References}

[1] Bieda A., Glanowska M., Hanus P., Pęska A.: Rozgraniczenie jako proces wspomagajacy procedury gospodarki nieruchomościami oraz planowania przestrzennego. Infrastruktura i Ekologia Terenów Wiejskich, nr 4, 2015, pp. 1067-1080.

[2] Bieda A., Jasiołek J., Hanus P.: Wykorzystanie klasycznych map ewidencyjnych w podstawowych pracach geodezyjnych. Infrastruktura i Ekologia Terenów Wiejskich, nr 4, 2011, pp. 193-202.

[3] Bieda A., Pęska A., Szałajko A.: Analiza czasu trwania postępowania w sprawie o rozgraniczenie nieruchomości. Acta Scientiarum Polonorum. Administratio Locorum, t. 15(1), 2016, pp. 15-29.

[4] Hanus P.: Analysis of Circulation of Information in Local Surveying Documentation Centre. Geomatics and Environmental Engineering, vol. 5, no. 2, 2011, pp. 31-41.

[5] Hanus P., Hycner R., Kwartnik-Pruc A.: Analiza terminologiczna wybranych problemów katastru i zagadnień pokrewnych. Cz. II. Prosto do katastru i mierniczego. Magazyn Geoinformacyjny Geodeta, nr 11, 2013, pp. 25-32.

[6] Hycner R., Hanus P., Kwartnik-Pruc A.: Analiza terminologiczna wybranych problemów katastru i zagadnień pokrewnych. Cz. I. Działka, granica, nieruchomość. Magazyn Geoinformacyjny Geodeta, nr 10, 2013, pp. 15-22.

[7] Kwartnik-Pruc A., Hanus P.: Geodezyjne aspekty rozgraniczeń i podziałów nieruchomości. Wydawnictwa AGH, Kraków 2014.

[8] Łuczyński R.: Granice działek w postępowaniu podziału nieruchomości. Przegląd Geodezyjny, nr 5, 2008, pp. 3-9.

[9] Łuczyński R.: Technologiczne i prawne aspekty wznawiania oraz ustalania przebiegu granic działek ewidencyjnych. Acta Scientiarum Polonorum. Geodesia et Descriptio Terrarum, t. 8 (3), 2009, pp. 23-38.

[10] Pęska A.: The Role of the Surveyor in the Real Estate Delimitation Run Turing Administrative and Court Procedure. Geomatics and Environmental Engineering, vol. 8, no. 2, 2014, pp. 71-84.

[11] Postanowienie Sądu Okręgowego w Słupsku z dnia 08.08.2013 r., sygn. akt IV Cz 417/13, publ. http://orzeczenia.slupsk.so.gov.pl. 
[12] Postanowienie Sądu Rejonowego w Łomży z dnia 09.10.2014 r., sygn. akt I Ca 202/14, publ. http://orzeczenia.lomza.so.gov.pl.

[13] Rozporzadzenie Ministrów Spraw Wewnętrznych i Administracji oraz Rolnictwa $i$ Gospodarki Żywnościowej z dnia 14 kwietnia 1999 r. w sprawie rozgraniczania nieruchomości. Dz.U. 1999, nr 45, poz. 453.

[14] Rozporzadzenie Ministra Rozwoju Regionalnego i Budownictwa z dnia 29 marca 2001 r. w sprawie ewidencji gruntów i budynków. Dz.U. 2001, nr 38, poz. 454 ze zm.

[15] Rozporzadzenie Ministra Spraw Wewnętrznych i Administracji z dnia 9 listopada 2011 r. w sprawie standardów technicznych wykonywania geodezyjnych pomiarów sytuacyjnych i wysokościowych oraz opracowywania i przekazywania wyników tych pomiarów do państwowego zasobu geodezyjnego i kartograficznego. Dz.U. 2011, nr 263, poz. 1572.

[16] Rozporzadzenie Ministra Administracji i Cyfryzacji z dnia 29 listopada 2013 r. zmieniajace rozporzadzenie w sprawie ewidencji gruntów i budynków. Dz.U. 2013, poz. 1551.

[17] Ustawa z dnia 14 czerwca 1960 r. Kodeks postępowania administracyjnego. Dz.U. 1960, nr 30, poz. 168 ze zm.

[18] Ustawa z dnia 17 maja 1989 r. Prawo geodezyjne i kartograficzne. Dz.U. 1989, nr 30, poz. 163 z późn. zm.

[19] Wyrok Naczelnego Sądu Administracyjnego z dnia 14.05.2010 r., sygn. I OSK 1009/09, [on-line:] http://orzeczenia.nsa.gov.pl.

[20] Wyrok Naczelnego Sądu Administracyjnego z dnia 29.07.2011 r., sygn. IOSK 1347/10, [on-line:] http://orzeczenia.nsa.gov.pl.

[21] Wyrok Wojewódzkiego Sądu Administracyjnego w Kielcach z dnia 06.09.2012 r., II SA/Ke 476/12, [on-line:] http://orzeczenia.nsa.gov.pl.

[22] Wyrok Wojewódzkiego Sądu Administracyjnego w Kielcach z dnia 26.06.2013 r., sygn. II SA/Ke 244/13, [on-line:] http://orzeczenia.nsa.gov.pl.

[23] Wyrok Wojewódzkiego Sądu Administracyjnego w Krakowie z dnia 30.01.2015 r., sygn. III SA/Kr 1766/14, [on-line:] http://orzeczenia.nsa.gov.pl.

\section{Praktyczne problemy realizacji wybranych procedur określających przebieg granic}

Streszczenie: Dużą część prac geodezyjnych zgłaszanych do ośrodków dokumentacji geodezyjnej i kartograficznej stanowią opracowania, których efektem końcowym jest określenie $\mathrm{w}$ terenie przebiegu granicy. Do momentu nowelizacji rozporządzenia w sprawie ewidencji gruntów i budynków ustalenie przebiegu granic pojedynczych działek ewidencyjnych możliwe było tylko w trybie ustawy Prawo geodezyjne $i$ kartograficzne. Obecnie możliwe jest zastosowanie procedury ustalenia przebiegu granic działek ewidencyjnych wykonywane na zlecenie podmiotów prywatnych na potrzeby aktualizacji operatu ewidencji 
gruntów i budynków. Przebieg granic na gruncie można określić także po przeprowadzeniu czynności wyznaczenia punktów granicznych ujawnionych uprzednio w ewidencji gruntów lub wznowienia znaków granicznych.

W artykule przeanalizowano opracowania geodezyjne sporządzone zgodnie z art. 39 ustawy Prawo geodezyjne $i$ kartograficzne oraz wykonywane zgodnie z § 39 rozporządzenia w sprawie ewidencji gruntów i budynków na potrzeby aktualizacji operatu ewidencji gruntów i budynków. Na podstawie dokonanej analizy wskazano problemy geodezyjno-prawne spowodowane nieprecyzyjnymi regulacjami, z którymi spotykają się wykonawcy podczas określania $\mathrm{w}$ terenie przebiegu granicy. W pracy przeanalizowano także materiały, które w świetle obowiązujących przepisów prawa mogą stanowić podstawę do przeprowadzenia czynności wznowienia znaków granicznych, wyznaczenia punktów granicznych oraz ustalenia przebiegu granic.

\section{Słowa}

kluczowe: ustalenie granic, wznowienie granic, ewidencja gruntów 